\title{
シンポジウム記録＼cjkstart震災被災地の水産業と漁村の復興
}

\section{I-1． 日本水産学会の震災復興対応}

\author{
黒倉 寿 1,2 \\ 1 日本水産学会水産政策委員会, \\ 2 東京大学大学院農学生命科学研究科
}

Activities of The Japan Society of Fisheries Science for reconstruction after the earthquake

HISASHI KUROKURA

${ }^{1}$ Policy-making Committee, ${ }^{2}$ Graduate School of Agricultural and Life Science, The University of Tokyo, Bunkyo, Tokyo 113-8657, Japan

平成 23 年 3 月 13 日に平成 23 年度第 2 回水産学会理 事会が行われた。この理事会は, 公益財団法人移行後に 新しい体制で行われる理事会としては実質的に初めて行 われるものであり，今後の方針を決める重要な理事会で あったが，当然，3 月 11 日の東日本大震災の復旧・復 興に対する日本水産学会の対応が中心的な話題となっ た。とりわけ, 日本水産学会春季大会の実施が差し迫っ た問題であった。この時点では，春季大会を予定通り実 施するという決定がなされた。今回の被災地が水産業を 基盤的な産業とする地域であることを考えると, 水産学 会は当事者の一部であり，事態に積極的に立ち向かう姿 勢を示すべきというのが主たる理由であった。その中 で，「水産業の震災復興に向けた臨時勉強会」を，3 月 29 日に行うことを決定した。その後, 福島の原発事故 により, 電力供給等に懸念が生じたため, 口頭発表。ポ スター発表を行わないことが決定された。このような経 緯で, 3 月 29 日の勉強会は, 水産学会が春季大会とし て行う唯一の活動となり，その内容に注目が集まった。 勉強会は当初の予想をはるかに上回る 300 人ほどの参 加者があり，社会的関心を集めていることが明瞭であっ た。内容は，復興プロセスに関する行政的な対応の経験 や，放射能污染に関するデーター蓄積の紹介など，極め て有効な情報に富むものであった。この時点で，指摘さ れた協業化の必要や放射能污染リスクに対する考え方 は，その後の議論に少なからぬ影響を与えている。この 勉強会の成果をもとに, 水産学会は「東日本大震災から の復興に向けた日本水産学会の行動計画」を作成，4月 11 日のこれを公表した。この行動計画は当初「提言」 として作成・発表することが企画されたが，作成段階 で，学会として主体的な取り組みが問われているとし て，自らの課題として「行動計画」を発表したものであ る。現在の水産学会の活動は, この「行動計画」に沿っ てなされている。その後, 政策委員会は, 政府の復興構 想会議のメンバーである馬場治東京海洋大学教授を新メ ンバーに加えるとともに，拡大政策委員会を組織し，東 京大学大気海洋研, 東北大学, 北里大学, 岩手. 宮城. 福島・茨木の水産試験場関係の代表者, 水産学会の各委 員会の代表，水産学会秋季大会の担当機関である長崎大 学の代表を加えて, 全国規模で一致協力して復興に取り 組む体制を組織した。また，復興支援拠点を東北支部に 置くことを決定し，7月 16 日には，「東日本水産業復興 対策緊急シンポジウム」を水産学会主催で行った。ここ では，被災地の現状が紹介されるとともに，水産加工業 の復興や加工団地の排水処理問題への取り組久など, 重 要な指摘がなされた。このような中で，政策委員会は，
復興に関して全国レベルの協力体制の構築が必要と考 え，そのための資金援助を各方面に㗢きかけてきたが， 今のところ，JKA より 300 万円の資金援助が得られて いる。現在, 具体的なプロジェクトの内容を詰めている が，被災地の諸機関を中心とした，全国レベルでの協力 体制の構築が課題となっている。また，水産学会秋季大 会では, 震災復興に関するシンポジウムが二つ行われた が，ここでは，漁業復興・漁村復興とともに，過剰な現 地調査による弊害 (視察公害), 水産加工施設の復興, 科学コミュニケーションのあり方等が話題となった。 る。

上記を含め，これまでの活動状況は以下のとおりであ

水産学会および関連団体の震災復興関連の活動

3 月 13 日 理事会

3 月 27 日 理事会

3 月 29 日 水産学会勉強会

4 月 7 日 学術会第 3 部を中心とする 22 学会（以下 22 学会）実務者連絡協議会発足

4 月 11 日 日本水産学会行動計画発表

5 月 27 日 22 学会

「巨大地震と大津波加ら国民の生命と国土 を守るための基本方針」発表

海洋基本法フォローアップ研究会

「東日本大震災復興に関する海洋産業の視 点加の緊急提言」発表

竹内会長意見表明

6 月 1 日 財団法人農学会・農学アカデミー「消費者 の不安に農学者が答える」一大震㷋・原発 事故・食の安全

6 月 4 日 理事会（政策委員に馬場治を加える，拡大 政策委員会設置)

東北大学支援拠点 資金援助 370 万円

6 月 8 日 学術会議東日本大震災対策委員会復興グラ ンドデザイン分科会「復興の目標と 7 つの 原則」発表

6 月 25 日 東日本大震災復興構想会議, 「復興への提 言〜悲惨の中の希望〜」発表

6 月 27 日 水産庁 水産復興マスタープラン発表

7 月 16 日 東日本水産業復興対策緊急シンポジウム

7 月 30 日 JKA より 300 万円の資金援助

8 月 11 日 東日本大震災復興対策本部「東日本大震災 からの復興の基本方針」発表

9 月 16 日 水産学会 22 学会の連続シンポジウム不参 加を決定

9 月 21 日 日本水産学会・災害復興拠点講演会

9 月 22 日 学術会議声明

9 月 28 日 漁業懇話会講演会「東日本大震災による漁 業被害 : 復興に向けた取り組みを考える」

9 月 30 日 日本学術会議東日本大震災対策委員会食料 科学委員会水産分科会「東日本大震災加ら 秦時代の水産業の復興」発表

日本学術会議東日本大震災対策委員会復興 グランドデザイン分科会「東日本大震災被 災地域の復興に向けて（第 2 次提案）」発 表

10 月 2 日 特別公開シンポジウム「震災被災地の水産 業と漁村の復興」

11 月 8 日 水産利用懇話会講演会「東日本大震苂後の 東北地方に抢ける水産豪の現状々今後の展 望一主に水産加工・流通について」 